\title{
China's Development Assistance in Sub-Saharan Africa: Challenges and Opportunities ${ }^{1}$
}

\begin{abstract}
As the increase of bilateral trade between China and sub-Saharan Africa in the last ten years has been skyrocketing at the expense of Western countries, paralleled by the renewed projection of Chinese soft power in the continent by means of technical aid and economic agreements, the author will analyse the scope, the underlying factors, and the potential consequences of Chinese development assistance to countries in the region. In a comparative manner, the paper also briefly describes the main features that make Chinese foreign assistance different from its Western counterpart. The author argues that there is a contradiction between the economic agenda of Beijing aimed at reproducing centre-periphery contradictions on the world stage with China at the centre of the envisaged world system, and a political discourse still based on the principle of non-interference and opposition to neo-colonialism.
\end{abstract}

Keywords: China, sub-Saharan Africa, development assistance, developing countries, economy

\section{Introduction}

In the last decade, China's development assistance to sub-Saharan Africa has attracted vivid attention from mass media and the general public as well, with the result that opinions are often polarised between those who depict China as a model for a more just and equitable cooperation between developing countries and those who blame Beijing for being simply interested in grabbing the African continent's natural resources without any concern for environmental consequences and human rights. ${ }^{2}$

Critical voices have blamed the Chinese model as neo-colonial, arguing that it is instrumental in consolidating the dominant position of Chinese capital, opening up new markets for Asian goods and obtaining access to untapped natural resources to sustain industrial development at home. Moreover, critical scholars have argued that there seems to be a negative correlation between Chinese aid and development in sub-Saharan Africa, because Beijing authorises autocratic rulers responsible for gross human rights violations to expand their financial portfolio and resist pressure from traditional donors for democratic change and good governance. ${ }^{3}$ In recent years, this critical perspective has been increasingly challenged by a new wave of scholarship that has focused on the positive

1 This publication was created in commission of the National University of Public Service under the priority project PADOP-2.1.2-CCHOP-15-2016-00001 entitled "Public Service Development Establishing Good Governance" in the framework of Africa in the Globalized World Ludovika Research Group.

2 Frynas, J. George - Paulo, Manuel: A New Scramble for African Oil? Historical, Political and Business Perspectives. African Affairs, Vol. 106, No. 423, 2007, pp. 229-251.

3 Kurlantzick, Josh: Charm Offensive: How China's Soft Power is Transforming the World. Yale University Press, New Haven, 2007. 
aspects of China's rise as a new global power. In particular, it has been argued that Chinese financial flows have positive effects on African sovereignty, because African rulers are now more able to stand as equal partners of the international community and may obtain funding for development projects that would not have otherwise been taken into consideration by international financial markets. ${ }^{4}$

In the next paragraphs, I will briefly describe the main features that make Chinese foreign assistance different from its Western counterpart. Then, I will analyse the scope, the underlying factors, and the potential consequences of Chinese development assistance to sub-Saharan Africa from the point of view of both the recipient countries and Western donors.

\section{A rising hegemon in sub-Saharan Africa}

Interest in the relationship between China and sub-Saharan Africa has been sparked by the skyrocketing increase of bilateral trade in the last ten years at the expense of Western countries, paralleled by the renewed projection of Chinese soft power in the continent by means of technical aid and economic agreements. ${ }^{5}$ Beijing's foreign aid program to sub-Saharan Africa is of particular interest because of its potential consequences on the restructuring of North-South relations as we have known them so far, but is nonetheless surrounded by opacity for what concerns its effective scope, structure, and purpose. Volumes of financial assistance provided by Beijing to sub-Saharan Africa have increased steadily at a rate of around $24 \%$ annually since 2004 : while China ranked $16^{\text {th }}$ in the global ranking of Africa's international donors in 2006; it was estimated that in 2017 it became the fifth largest donor. ${ }^{6}$ China's presence is evenly spread throughout the African continent, but several countries have gained privileged attention. The most notable ones among them are Ghana, the Democratic Republic of Congo, Ethiopia, Mauritania and Nigeria, but official data often hide a more complex picture and cannot be taken for granted.?

When compared to the theory and practice of other Western aid programmes, the foreign aid policy of Beijing stands up for several differences that make it a sort of model of "South-South" cooperation. First of all, China - at least officially - insists on the principle of non-interference in the domestic affairs of its African partners, thereby rejecting the human rights narrative and the architecture of conditionality manufactured by Western countries in their relationship with sub-Saharan Africa since the early 1980s. Second, China tends to privilege donations and investments in economic sectors that have been abandoned by Western foreign aid in the last twenty years, such as construction and infra-

\footnotetext{
Wang, Xiaobing - Ozanne, Adam: Two Approaches to Aid in Africa. Paper presented at the International Conference "Ten Years of War against Poverty", University of Manchester, September 2010.

China’s Growing Role in UN Peacekeeping, [online] Asia Report No. 166, April 2009. Source: International Crisis Group [20.09.2017.]

6 Kitano, Nahoiro - Harada, Yukinori: Estimating China’s Foreign Aid, 2001-2013. JICA-RE Working Paper, No. 78, June 2014.

7 Strange, Austin et al.: Tracking Under-Reported financial Flows: China Development Finance and the Aid-Conflict Nexus Revisited, [online], Discussion Paper Series 553, University of Heidelberg, January 2014. Source: Sagepub [28.08.2017.]; Strange, Austin et al.: China’s Development Finance to Africa: a Media-Based Approach to Data Collection, [online], Working Paper No. 323, April 2013. Source: Center for Global Development [11.08.2017.]
} 
structure. Chinese foreign assistance is often focused on large projects such as stadiums and government buildings, which are particularly welcomed by host governments in so far as they provide visibility and help to build consensus among the general public. Examples of projects of this kind can be found in different countries such as Eritrea, Somalia, Djibouti, Uganda and Gabon, just to cite a few. Third, Chinese aid is often deemed to be more suitable to the administrative performance of African countries. In fact, Western aid is usually paralleled by the creation of specific country assistance strategies that reflect donors' goals in terms of improved governance and represent a burden for the counterpart's bureaucratic apparatus. Chinese aid, on the contrary, is more flexible, both because of its focus on turnkey infrastructural projects and because Chinese advisors attached to the project are far cheaper than Western economic counsellors. Another difference between Chinese and Western development assistance is visible in loan repayment procedures. Chinese loans are often backed by rights of exploitation over the host country's natural resources: a sort of a barter that authorises many African countries to broaden their external debt portfolio in spite of the already precarious state of their public budget and their high exposure to international creditors. Western donors, on the other hand, are more concerned with long-term debt sustainability and are, therefore, reluctant to release new loans to countries that are deemed to be close to default. Finally, Western and Chinese aid agencies employ different parameters to evaluate the sustainability of borrowing countries' public debt: World Bank and the International Monetary Fund employ general macro-economic data and statistics to evaluate the counterpart's solvability and capacity to support new loans, while Beijing looks at the capacity of a single project to repay itself. Such differences are critical, because it means that China occasionally may authorise large loans that otherwise would not have been granted by Western donors. A case in point is Djibouti, which received a large loan at non-concessional terms from China in 2013 amounting to 60\% of its Gross Domestic Product (GDP) for construction of the Djibouti-Addis Ababa railway and a water pipeline to Ethiopia. The IMF criticised this loan pointing out the excessive burden for the country's financial stability, but China deemed the railway project to be likely to promote an increase in trade revenues that would make it sustainable in the long term. ${ }^{8}$

\section{Development aid or financial flows?}

China's foreign aid programme to the Global South in general and sub-Saharan Africa in particular, is often described in emphatic terms as a proof of Beijing's new hegemonic status in the African continent. ${ }^{9}$ The idea of China as a new donor superpower is nonetheless based on contradictory data that are more often, than not, exaggerated to sustain the validity of the underlying thesis. This methodological shortfall is due to several reasons. First, it is the outcome of the Chinese Government's reluctance to release accurate statistics on its international cooperation programs. Second, there is a problem in defining what

\footnotetext{
8 International Monetary Fund: Djibouti, Staff Report for the 2014 Article IV Consultation - Debt Sustainability Analysis, [online], 15.01.2015. Source: IMF.org [13.08.2017.]

9 The New Colonialists: a fourteen-page report on China's thirst for natural resources, [online], 13.03.2008. Source: The Economist [10.08.2017.]
} 
should be accounted for when talking about "aid". Indeed, one of the main problems for scholars who study the peculiarities of Chinese development assistance consists of distinguishing between foreign aid proper and other financial transactions, such as bank loans or state guarantees against export credits.

According to the definition provided by the Organization for Economic Development and Cooperation (OECD) in 1972, aid consists of "flows of official financing administered with the promotion of the economic development and welfare of developing countries as the main objective and which are concessional in character with a grant element of at least 25 per cent (using a fixed 10 per cent rate of discount)". ${ }^{10}$ Moreover, there are a few transactions that are excluded in principle from the aid category, such as military supplies and financial packages aimed at supporting, in full or in part, private direct investments and the export of goods from the donor country. The Chinese Government, however, has a much broader interpretation of what should be deemed to be included within the legal framework of international aid. For Beijing, foreign aid consists of donations; interest rate-free loans; and loans at subsidised interest rates, but with a critical difference if compared with the OECD definition. Indeed, foreign aid also includes loans against military supplies and economic measures aimed at supporting Chinese business groups overseas. ${ }^{11}$ Apparently, OECD countries have a much stricter understanding of what aid should be and look at international assistance as a tool to promote international solidarity, without any advantage for the donor country. As Brautigham has noted, however, the solidaristic character of the OECD definition has been overruled by the sharp decrease of interest rates on official financial markets in the last decades. Indeed, in recent years market interest rates at the London stock exchange have floated between 1 and 4\%, with the perverse effect that an ordinary loan at market interest rates provided by an OECD country might qualify as aid, although more favourable terms could be negotiated with private international banks. ${ }^{12}$

Another difference between the Chinese and the Western models of international cooperation lays in the organisational structure. Western countries usually tend to concentrate every prerogative related to the elaboration of foreign aid policy and its enforcement on specialised government agencies such as the United States International Aid Agency (USAID) or the British Overseas Development Ministry (ODM). In China, however, foreign aid is managed by a wide array of government agencies with different functional prerogatives, such as the Import-Export Bank and the Ministry of Commerce. The latter is specifically tasked with the management of donations and interest rate-free loans to other countries, while the China Exim Bank is trusted with the management of commercial loans at more or less favourable interest rates. The Ministry of Finance, in turn, is responsible for the authorisation and release of government subsidies to cut the ordinary interest rates attached to commercial loans from Exim Bank. ${ }^{13}$

10 Organization for Economic Cooperation and Development: DAC in Dates: The History of OECD's Development Assistance Committee, [online], 2006. Source: OECD [23.04.2018.]

11 Brautigam, Deborah: Aid 'With Chinese Characteristics': Chinese Foreign Aid and Development Assistance Meet the DAC-OECD Aid Regime. Journal of International Development, Vol. 23, No. 5, 2011, pp. 752-764.

12 Ibid. 755

13 Brautigam, Deborah: China's African Aid: Transatlantic Challenges, [online], 2008. Source: The German Marshall Fund of the United States [19.09.2017.] 
Another difficult issue that arises when comparing foreign aid measures from China and from other Western countries is related to the complex nature of Chinese economic packages. Many economic agreements between China and the African countries are composed of different financial tools provided by different government agencies, and only some of them are concessional in character as required by the OECD definition of "aid". According to a survey made in 2006, only $3 \%$ of China Exim Bank's loans can be classified in this category, while the remaining $97 \%$ is mostly composed of export credits and loans at commercial interest rates, which are depicted by the OECD under the category of "other financial flows". ${ }^{14}$ Nevertheless, according to the White Book of Foreign Aid published by Beijing in 2011, the picture was very different. Government sources estimated that the overall foreign aid budget overseas consisted of donations (41.4\%), loans without any interest rate (29.9\%) and loans at subsidised interest rates (28.7\%). ${ }^{15}$ Arguably, it is very difficult to trace back and verify such a volume of overlapping data and draw a clear-cut line between Chinese foreign aid and the ordinary financial activity of export agencies and commercial banks overseas. Not incidentally, research reports and articles that deal with quantitative data concerning China's foreign aid program often provide radically different conclusions: only in relation to the year 2007, the overall foreign aid estimates range between 582 million and 1.4 billion U.S. dollars. ${ }^{16}$

\section{Driving factors of Chinese foreign assistance}

In spite of its alleged solidaristic and universal character, development assistance is a typical instrument of a country's foreign policy and is distributed in pursuit of its "national interest". In this regard, China's South-South cooperation makes no exception. The historical goal of the Chinese Communist Party (CCP) since the early 1950s has consisted in isolating the Taiwanese competitor on the other bank of the sea: to this end, the CCP skilfully employed its nascent foreign aid program to independent African countries to gain their favour within the General Assembly of the United Nations and be recognised as the sole representative of China. Today, Beijing continues to march on the same path, balancing its foreign aid exposure to sub-Saharan Africa according to the principle of the carrot and the stick. ${ }^{17}$ Today, only three African countries sill recognise and entertain diplomatic relations with Taipei. ${ }^{18}$ One of them, Swaziland, is the only African country that does not benefit from any foreign assistance package from Beijing. On the other hand, this strategy has proved to be useful in 2008, when Malawi decided to cut every relation with Taiwan in return for the promise of a large foreign aid program, only a share of which has so far materialised. The cases of Malawi and other countries highlight how the strategy of the stick and

\footnotetext{
14 Brautigam (2011): op. cit.

15 China's Foreign Aid, [online], April 2011. Source: Information Office of the State Council, The People's Republic of China, Beijing [22.09.2017.]

16 Lum, Thomas et al.: China's Foreign Aid Activities in Africa, Latin America, and South East Asia, [online], 25.02.2009. Source: Congressional Research Service Report for Congress [13.09.2017.]; Lancaster, Carol: The Chinese Aid System, [online], 27.06.2007. Source: Center for Global Development Essay [22.09.2017.]

17 Lum et al. (2009): op. cit. 9.

18 Rich, Steven Timothy - BAnerjeE, Vasabjit: Running out of time? The evolution of Taiwan's relations in Africa. Journal of Current Chinese Affairs, Vol. 44, No. 1, 2015, pp. 141-161.
} 
the carrot may be manipulated by African countries as well, since they can bargain formal declarations or diplomatic announcements without far reaching consequences in return for large inflows of hard currency at favourable terms. Ethiopia, for instance, successfully resorted to this strategy in 2005, when the federal parliament approved a resolution in favour of the anti-secessionist law promulgated by Beijing. In the span of a few years, Addis Ababa became one of the main beneficiaries of Chinese foreign aid in the continent. ${ }^{19}$

The second factor shaping patterns of Chinese international cooperation is of an economic nature and is materialised in opening new markets for Chinese goods overseas. Beijing's interest for commercial opportunities in Africa has increased rapidly in recent years in parallel with the fast growth of bilateral trade, which stepped up from 10 billion U.S. Dollars in 2000 to 107 billion in 2008 and 170 billion in 2017. ${ }^{20}$ Africa has become a potential market for Chinese goods after a decade of double-digit growth in different parts of the continent, but it is also a strategic site for importing raw material and energy supply, since one quarter of the Chinese oil purchased from abroad is actually imported from Africa. Of particular interest are, in this regard, the renowned resource-for-infrastructure packages granted by Beijing to oil producing African countries. Under this specific arrangement, China provides the counterpart with donations and long-term loans in return for the assignment of oil exploitation rights to Chinese companies overseas, while profits from oil commercialisation are directly channelled through a government-controlled trust fund to make it sure that costs from debt repayment are met: ${ }^{21}$ a solution welcomed by countries such as Ghana, Nigeria or Angola, which exploited their environmental resources to secure an infrastructural loan at more favourable terms than those offered by commercial banks.

Bilateral trade growth with Africa is currently one of the main priorities of the Chinese Government: to this end, in 2006 Beijing decreased import-export tariffs over a wide array of products imported from 25 African countries. ${ }^{22}$ The Chinese private sector is probably the greatest beneficiary of international development assistance through the practice of tying foreign aid to the provision of Chinese services and goods from Chinese companies. To this end, the Chinese Government centralises all transaction procedures related to the purchase of goods covered by foreign aid packages to a third country. Support to overseas business firms is not a hidden goal, but it is an integral part of the rationale and narrative of Chinese international assistance. In fact, South-South cooperation is permeated with a win-win rhetoric that frames foreign aid as a tool to create a profitable relationship for all parties involved, and not only the beneficiary. ${ }^{23}$

19 Eisemann, Joshua: China's Post-Cold War Strategy in Africa: Examining Beijing's Methods and Objectives. In: Eisemann, Joshua - Heginbotham, Erik - Mitchell, Derek (eds.): China and the Developing World: Beijing's Strategy for the Twenty-First Century. East Gate, London, 2007, pp. 29-59.

20 Holslag, Jonathan: China and the Coups: Coping with Political Instability in Africa. African Affairs, Vol. 110, No. 440, 2011, p. 378; Ministry of Commerce of the People's Republic of China, Statistics on China-Africa bilateral trade in 2017, [online], 26.01.2018. Source: English.mofcom.gov.cn [20.04.2018.]

21 Vines, Alex - Wong, Lilian - Weimer, Markus - Campos, Indira: Thirst for African Oil: Asian National Oil Companies in Nigeria and Angola, [online], 10.08.2009. Source: Chatham House [10.09.2017.]

22 Sideri, Sandro: La Cina e gli Altri, Nuovi Equilibri della Geopolitica, [online], 2011. Source: Istituto per gli Studi di Politica Internazionale [10.09.2017.]

23 Campos, Indira - VIneS, Alex: Angola and China: a Pragmatic Partnership, [online], 06.03.2008. Source: CSIS [09.09.2017.] 
It is difficult to state clearly whether Chinese involvement in sub-Saharan Africa is driven by political factors linked to the diplomatic dispute with Taiwan or by the desire to support Chinese economic growth and secure a stable supply of raw materials. The dominant narrative we may find in the Western media that usually depicts China as an emerging power determined to exploit its commercial surplus for gaining control of indebted countries' natural resources, thereby embracing the second thesis. ${ }^{24}$ In support of this argument, it has been underlined that the Ministry of Commerce is the government entity tasked with the management of donations and interest-free loans, which form the bulk of foreign aid. The regulation arguably has far-reaching consequences for the bureaucratic rationale of development assistance, since public servants within the Ministry of Commerce are inevitably inclined to frame the national interest in terms of expansion of favourable trading relations. The intelligibility between development assistance and access to natural resources overseas is further confirmed by the fact that more than $70 \%$ of Chinese financial flows invested in infrastructure development overseas are concentrated in countries that are major oil exporters to China or where Chinese companies are engaged in soil exploration. ${ }^{25}$ Finally, the same turnkey projects where Beijing is responsible for both the financing and the construction of single infrastructures structured in a way that Chinese concessionary companies may enter the national market from a dominant position and outbid potential rivals. ${ }^{26}$

These conclusions are not univocal, however. First of all, the statistics on the causal relationship between overall allocation of financial flows overseas and the availability of oil resources in the host country include foreign aid from the Ministry of Commerce and other financial flows from China Exim Bank as well, which means that the overall amount of Chinese international aid as such is overestimated. ${ }^{27}$ Further research on the interconnection between foreign aid, bilateral trade and variations in oil production in recipient countries have showed how, once eliminated from the equation any line of credit that is not concessional in character, Chinese international cooperation is not exclusively driven by the purpose to take control of other countries' natural resources. ${ }^{28}$ In other words, Chinese foreign aid policy is more concerned with traditional goals usually pursued by other Western aid agencies such as raising diplomatic consensus among recipient governments in the Global South. ${ }^{29}$

24 Neocolonialismo cinese in Africa, [online], 09.10.2013. Source: L'Indro [28.08.2017.]; The World in Their Hands, [online], 13.01.2012. Source: The Economist [22.09.2017.]

25 Lum et al. (2009): op. cit. 10.

26 Davies, Martyn - Edinger, Hannah - TAy, Nastasya - NAidu, Sanusha: How China Delivers Development Assistance to Africa, [online], February 2008. Source: Centre for Chinese Studies, University of Stellenbosch [20.08.2017.]

27 Brautigam, Deborah: China, Africa and the International Aid Architecture. African Development Bank Working Paper Series, No. 107, 2010, p. 21.

28 Drener, Axel - Fuchs, Andreas: Rogue Aid? The Determinants of China's Aid Allocation. Courant Research Centre Discussion Paper, No. 93, 2011.

29 Drener, Axel et al.: Apples and Dragon Fruits: The Determinants of Aid and Other Forms of State Financing from China to Africa. Aid Data Working Paper, No. 15, October 2015. 


\section{The impact of the Chinese development assistance on beneficiary countries}

A feature of Chinese development assistance that has been often criticised by traditional donors is the lack of conditionality. According to critics, in fact, the absence of conditionality hinders efforts of transnational financial institutions and OECD countries against corruption and in support of transparency in the management of public budgets. ${ }^{30}$ What traditional donors criticise the most is the practice of negotiating development packages directly with highest authorities in the host country, often bypassing checks-and-balance institutions and accountability mechanisms. The consequence, according to the opponents of this practice, is that such behaviour authorises host governments to use development aid for fostering patron-client relationships at the expense of good governance and institutional growth.

The argument of a correlation between Chinese aid and corruption is supported by a recent research on the geographical distribution of aid projects financed by China in the African continent. Accordingly, Chinese-financed development projects managed by the host government tend to be concentrated in those regions where standing African rulers were born or where they have a big popular support. The conclusion suggested by this research is that the relative freedom provided by the lack of conditionality is an incentive for African governments to promote development projects whose main goal is to raise a popular consensus among the government's supporters, and not to encourage economic growth as a whole. ${ }^{31}$ In a similar fashion, other works have underlined how Chinese aid is often intertwined with the increase of political violence in the host country. The underlying thesis is the same: the lack of conditionality allows host governments to employ aid resources for enforcing population control and repressing dissent instead of strengthening the social pact with the citizenry as a whole. ${ }^{32}$

Critics of the Chinese model can be found also within the so-called civil society. A survey conducted in Uganda, for instance, suggests how Chinese aid projects are often perceived in a negative light by the population if compared with aid projects from other major powers such as the United States of America. ${ }^{33}$ Grievances are usually concentrated on the poor quality of the supplied material, the lack of transparency in the assignment of local contracts, the fact that local manpower is often excluded in favour of Chinese manpower and that Chinese aid is usually followed by the entrance of Chinese firms which are far more competitive than African ones, with the side effect that large sectors of the

30 Woods, Ngaire: Whose Aid? Whose Influence? China, Emerging Donors, and the Silent Revolution in Development Assistance. International Affairs, Vol. 84, No. 6, 2008, pp. 1205-1221.

31 Drener, Axel et al.: Aid on Demand: African Leaders and the Geography of China's Foreign Assistance. Aid Data Working Paper, No. 3, November 2014. Another work dealing with patterns of allocation of Western aid in Zambia since 1960 nonetheless argues for the opposite argument, since it shows how African rulers usually concentrate development aid in opposition strongholds in order to expand their constituency. See MASAKI, Takaaki: The Political Economy of Aid Allocation in Africa: the Case of Zambia. Aid Data Working Paper, No. 5, January 2015.

32 KIshi, Roudabeh - RAleigh, Clionadh: Chinese Aid and Africa's Pariah States, [online], 2015. Source: ACLED [08.09.2017.]

33 Miller, Helen - Nelson, Daniel - Findley, Michael: Which Devil in Development? A Randomized Study of Citizens Actions Supporting Foreign Aid in Uganda. Working Paper, Princeton University, 2013. 
local business community are displaced from the market. These kinds of grievances have been registered in different countries such as Angola, Nigeria, Ethiopia and Zambia. ${ }^{34}$

In contrast with these arguments, however, it should be pointed out that a large share of existing research is often based on contradictory data, because of the reluctance of the Chinese Government in showing its official aid program. Moreover, negative aspects coexist with positive ones, first of all the fact that Chinese assistance broadened the availability of fresh capital at the disposal of African governments. Be it in the form of foreign aid proper or other financial flows at more or less commercial terms, Beijing's projection in sub-Saharan Africa has increased the bargaining leverage of African countries in negotiating the content of the aid relationship with traditional donors, sanctioning the fall of Western powers' de facto monopoly in the realm of development assistance after the end of the Cold War.

The case of Angola is paradigmatic of the positive relationship between the rise of China as a major world power and African sovereignty, but it is also illuminating the limitations of the rhetoric that depicts Beijing as an irresponsible member of the donors' community. ${ }^{35}$ Between 2002 and 2004, the Angolan Government engaged in harsh negotiations with the International Monetary Fund (IMF) to reschedule its public external debt, which had skyrocketed in previous years because of the civil war. In return for support, the IMF requested Angola to promote a large-scale privatisation program involving some major state-owned public companies, along with the establishment of accountability mechanisms to make the public budget more transparent. Negotiations were abruptly interrupted in 2004, when the Angolan Government entered into a 2 billion dollars infrastructural loan with China Exim Bank for the re-construction of the country's railway line. The agreement provoked harsh reactions among Western media, because for the first time it revealed the limitations of IMF conditionality power in presence of an alternative source of finance. Moreover, the deal was one of the first and more significant examples of the resource-for-infrastructure package in so far as the Chinese Government secured the loan in return for long-term oil exploitation concessions to the public company China Petroleum and Chemical Corporation. The involvement of a state-owned oil company was taken by the media as an example of how Beijing was determined to use its foreign aid program to grab Africa's natural resources instead of promoting the well-being of the host country. ${ }^{36}$

The Angolan case study is interesting also because it shows the gap between the narrative and reality. First of all, concerns that aid was allegedly granted in return for oil were baseless: the loan was not part of Beijing's official foreign aid program, since it was released by China Exim Bank on commercial terms without any subsidy being granted by the Ministry of Finance. Second, China was not the first country to "break the ice" and entertain independent negotiations with the Angolan Government bypassing the IMF, since at that time Germany had already violated the Bretton Woods organisation's prescriptions and

\footnotetext{
34 Vines et al. (2009): op. cit. 41; Quigley, Sam: Chinese Oil Acquisitions in Nigeria and Angola, [online], 01.06.2014. Source: American University at Cairo [12.06.2017.]

35 Kjollesdal, Kristian A. - Welle-Strand, Anne: Foreign Aid Strategies: China Taking Over? Asian Social Science, Vol. 6, No. 10, 2010, p. 9.

36 VINEs et al. (2009): op. cit. 33-48.
} 
stipulated an export credit package with Luanda without consultation with other members of the Development Assistance Committee (DAC). Finally, the resource-for-infrastructure package was not an innovation introduced by Beijing, since Angola had already signed similar contracts with other Western private commercial banks that had secured their loan against oil sales. The only difference between the latter contracts and the Chinese one was that China Exim Bank's deal was more generous, since the Chinese bank was able to offer longer terms of repayment at lower interest rates. ${ }^{37}$ In the end, the Chinese loan and the growth of oil prices on international markets allowed the Angolan Government to improve its bargaining position vis-a-vis the IMF and obtain a reschedule of its external debt with private commercial banks without abiding by the most pressing demands in terms of privatisation and budget accountability. ${ }^{38}$

\section{The impact of the Chinese development assistance on Western aid architecture}

The potential impact of Chinese development assistance on the scope and organisation of Western international aid is still a relatively neglected topic. At the moment, however, it is already possible to see a correlation between the innovations introduced by the Chinese South-South cooperation and the new approach advocated by several DAC countries on the development aid topic.

A first example in this direction is provided by the on-going debate on the legitimacy of tied aid, which is the practice of making the release of foreign aid packages contingent on the purchase of service and goods produced by firms associated to the donor's national economy. Tied aid was a common practice in the second half of the $20^{\text {th }}$ century, but came under growing attack of several countries and international organisations, because it was deemed to give an improper advantage to the donor's economy and deprive foreign aid of its solidarity character. In 2001, the OECD adopted a recommendation that invited all member countries to untie foreign aid in order to improve its efficacy and provide a greater freedom to the final use of money to the beneficiary. Nevertheless, the advance of Chinese development assistance and the interconnection between Chinese aid and Chinese private investments has reversed this trend: today, more and more actors from the private sector and the business community are pressing for the re-establishment of tied aid as a tool to counterbalance the loss of market shares in sub-Saharan Africa. ${ }^{39}$

A second example of how Chinese intervention is shaping the behaviour of Western donors is offered by a recent research on the relationship between the World Bank and several African countries that are at the same time beneficiaries of Chinese assistance. In these cases, although the Bretton Woods organisation is usually the proponent of the principle that development aid should be subordinated to the recipient country's adoption

\footnotetext{
Brautigam, Deborah: The Dragon's Gift: The Real Story of China in Africa. Oxford University Press, Oxford, 2009, pp. $273-277$.

38 Bracken, Andrew et al.: China's Quest for Energy Security: Redefining and Driving Foreign Aid. The Michigan Journal of Public Affairs, Vol. 10, 2013, pp. 4-29.

39 Condon, Madison: China in Africa: What the Policy of Non-Intervention Adds to the Western Development Dilemma. Praxis - The Fletcher Journal of Human Security, Vol. 27, 2012, pp. 5-25.
} 
of macro-economic and institutional reforms for improving good governance, it emerged that conditionality measures imposed by the World Bank have decreased on average by $15 \%$ for each percentage point positive variation in the volume of the Chinese financial assistance to that country. This negative correlation is largely the outcome of the World Bank's diminished leverage over its African partners, which can obtain access to development aid from other sources without being submitted to limitations of their internal sovereignty. ${ }^{40}$

\section{Conclusions}

The Chinese establishment has for long criticised Western interventions in sub-Saharan Africa, promoting the idea that foreign aid and private investments were two sides of the same coin in so far as they were aimed at reproducing neo-colonialism through the transformation of political subordination into a more subtle form of economic subordination. The win-win rhetoric that today permeates the principles of South-South cooperation, of which China is the most prominent actor worldwide, clashes nonetheless with a reality where China is at the height of a new world hierarchy where Africa is still at the bottom, providing Beijing and its industrial apparatus with cheap raw material and new market outlets. ${ }^{41}$ The paradox is that the Chinese Communist Party is going to become a victim of the contradiction between an economic agenda aimed at reproducing centre-periphery contradictions on the world stage with China at the centre of the envisaged world system, and a political discourse still based on the principle of non-interference and opposition to neo-colonialism. Chinese hypocrisy is to a certain extent similar to that of Western donors, whose adherence to general principles such as the promotion of democracy and respect for human rights varies according to the weight of economic and political interests at stake in the recipient country.

The rise of Chinese financial assistance to sub-Saharan Africa is without doubt positive news for many African rulers who made the management of external rents and development aid the backbone of their political career. In fact, Chinese financial flows in the form of concessional aid or ordinary loans at more or less commercial terms are suitable to broaden the extraversion portfolio of African governments and authorise them to mobilise larger economic resources at lower political cost. For these reasons, a radical rethinking of the theory and practice of the Western aid architecture in Africa is currently under way among scholars and government circles as well, in order to make it more suitable to the needs and challenges of the new multipolar order we live in.

40 Hernandes, Diego: Are New Donors Challenging World Bank Conditionality? Aid Data Working Paper, No. 19, January 2016.

41 Djiagne, Sijh: Undergraduate Comment: Development or Dependence? The China Factor in Senegal. Northwestern Interdisciplinary Law Review, Vol. 3, No. 1, 2010, pp. 211-224; SмIтн, Karen Elizabeth: The Use of Political Conditionalities in the EU's relations with Third Countries: How Effective? Paper for the ECSA International Conference, Seattle, 1997; Hagmann, Tobias - Reyntjens, Filip: Introduction: Aid and Authoritarianism in sub-Saharan Africa after 1990. In: Hagmann, Tobias - Reyntjens, Filip (eds.): Aid and Authoritarianism in Africa: Development without Democracy. ZED Books, London, 2016, pp. 1-20. 


\section{REFERENCES}

Bracken, Andrew - HajJ, Christina - Hartman, Kristine - Sivalingam, Shivan: China’s Quest for Energy Security: Redefining and Driving Foreign Aid. The Michigan Journal of Public Affairs, Vol. 10, 2013, pp. 4-29.

Brautigam, Deborah: Aid 'With Chinese characteristics': Chinese Foreign Aid and Development Assistance Meet the DAC-OECD Aid Regime. Journal of International Development, Vol. 23, No. 5, 2011, pp. 752-764. DOI: https://doi.org/10.1002/jid.1798

Brautigam, Deborah: China, Africa and the International Aid Architecture. African Development Bank Working Paper Series, No. 107, 2010.

Brautigam, Deborah: China's African Aid: Transatlantic Challenges, [online], 2008. Source: The German Marshall Fund of the United States [19.09.2017.]

Brautigam, Deborah: The Dragon's Gift: The Real Story of China in Africa. Oxford University Press, Oxford, 2009.

CAmpos, Indira - VINES, Alex: Angola and China: a Pragmatic Partnership, [online], 06.03.2008. Source: CSIS [09.09.2017.]

China's Foreign Aid, [online], April 2011. Source: Information Office of the State Council, the People's Republic of China, Beijing [22.09.2017.]

China’s Growing Role in UN Peacekeeping, [online] Asia Report No. 166, April 2009. Source: International Crisis Group [20.09.2017.]

Condon, Madison: China in Africa: What the Policy of Non-Intervention Adds to the Western Development Dilemma. Praxis - The Fletcher Journal of Human Security, Vol. 27, 2012, pp. 5-25.

DAvies, Martyn - Edinger, Hannah - TAY, Nastasya - NAIdu, Sanusha: How China Delivers Development Assistance to Africa, [online], February 2008. Source: Centre for Chinese Studies, University of Stellenbosch [20.08.2017.]

DJiagne, Sijh: Undergraduate Comment: Development or Dependence? The China Factor in Senegal. Northwestern Interdisciplinary Law Review, Vol. 3, No. 1, 2010, pp. 211-224.

Dreher, Axel - Fuchs, Andreas: Rogue Aid? The Determinants of China's Aid Allocation. Courant Research Centre Discussion Paper, No. 93, 2011. DOI: https://doi.org/10.2139/ssrn.1926471

Dreher, Axel - Fuchs, Andreas - Bradley, Parkes - Strange, Austin - Tierney, Michael: Apples and Dragon Fruits: The Determinants of Aid and Other Forms of State Financing from China to Africa. Aid Data Working Paper, No. 15, October 2015. DOI: https://doi.org/10.2139/ssrn.2674601

Dreher Axel - Fuchs, Andreas - Hodler, Roland - Parks, Bradley - Raschky, Paul - Tierney, Michael: Aid on Demand: African Leaders and the Geography of China's Foreign Assistance. Aid Data Working Paper, No. 3, November 2014. DOI: https://doi.org/10.2139/ssrn.2531966

Eisemann, Joshua: China's Post-Cold War Strategy in Africa: Examining Beijing's Methods and Objectives. In: Eisemann, Joshua - Heginbotham, Eric - Mitchell, Derek (eds.): China and the Developing World: Beijing's Strategy for the Twenty-First Century. East Gate, London, 2007, pp. 29-59. DOI: https://doi. org/10.4324/9781315642413-2

Frynas, J. George - Paulo, Manuel: A New Scramble for African Oil? Historical, Political and Business Perspectives. African Affairs, Vol. 106, No. 423, 2007, pp. 229-251. DOI: https://doi.org/10.1093/afraf/adl042

Hagmann, Tobias - Reyntjens, Filip: Introduction: Aid and Authoritarianism in sub-Saharan Africa after 1990. In: Hagmann, Tobias - Reyntjens, Filip (eds.): Aid and Authoritarianism in Africa: Development without Democracy. ZED Books, London, 2016, pp. 1-20.

Hernandes, Diego: Are New Donors Challenging World Bank Conditionality? Aid Data Working Paper, No. 19, January 2016.

HolsLAg, Jonathan: China and the Coups: Coping with Political Instability in Africa. African Affairs, Vol. 110, No. 440, 2011, pp. 367-386. DOI: https://doi.org/10.1093/afraf/adr022

International Monetary Fund: Djibouti, Staff Report for the 2014 Article IV Consultation - Debt Sustainability Analysis, [online], 15.01.2015. Source: IMF.org [13.08.2017.] DOI: https://doi.org/10.5089/9781513538570.002

Kjollesdal, Kristian A. - Welle-Strand, Anne: Foreign Aid Strategies: China Taking Over? Asian Social Science, Vol. 6, No. 10, 2010, pp. 3-13. DOI: https://doi.org/10.5539/ass.v6n10p3 
Kishi, Roudabeh - RALEIGH, Clionadh: Chinese Aid and Africa’s Pariah States, [online], 2015. Source: ACLED [08.09.2017.]

Kitano, Nahoiro - Harada, Yukinori: Estimating China’s Foreign Aid, 2001-2013. JICA-RE Working Paper, No. 78, June 2014. DOI: https://doi.org/10.1002/jid.3081

KurlantzicK, Josh: Charm Offensive: How China's Soft Power is Transforming the World. Yale University Press, New Haven, 2007.

Lancaster, Carol: The Chinese Aid System, [online], 27.06.2007. Source: Center for Global Development Essay [22.09.2017.]

Lum, Thomas - Fischer, Hannah - Gomez-Granger, Julissa - Leland, Anne: China's Foreign Aid Activities in Africa, Latin America, and South East Asia, [online], 25.02.2009. Source: Congressional Research Service Report for Congress [13.09.2017.]

Masaki, Takaaki: The Political Economy of Aid Allocation in Africa: the Case of Zambia. Aid Data Working Paper, No. 5, January 2015.

Miller, Helen - Nelson, Daniel - Findley, Michael: Which Devil in Development? A Randomized Study of Citizens Actions Supporting Foreign Aid in Uganda. Working Paper, Princeton University, 2013. DOI: https:// doi.org/10.2139/ssrn.2134409

Ministry of Commerce of the People's Republic of China, Statistics on China-Africa bilateral trade in 2017, [online], 26.01.2018. Source: English.mofcom.gov.cn [20.04.2018.]

Neocolonialismo cinese in Africa, [online], 09.10.2013. Source: L'Indro [28.08.2017.]; The World in Their Hands, [online], 13.01.2012. Source: The Economist [22.09.2017.]

Organization for Economic Cooperation and Development: DAC in Dates: The History of OECD's Development Assistance Committee, [online], 2006. Source: OECD [23.04.2018.]

Quigley, Sam: Chinese Oil Acquisitions in Nigeria and Angola, [online], 01.06.2014. Source: American University at Cairo [12.06.2017.]

Rich, Steven Timothy - BANERJEE, Vasabjit: Running out of time? The evolution of Taiwan's relations in Africa. Journal of Current Chinese Affairs, Vol. 44, No. 1, 2015, pp. 141-161. DOI: https://doi.org/10.1177/186810261504400106

SidERI, Sandro: La Cina e gli Altri, Nuovi Equilibri della Geopolitica, [online], 2011. Source: Istituto per gli Studi di Politica Internazionale [10.09.2017.]

Sмiтh, Karen Elizabeth: The Use of Political Conditionalities in the EU's relations with Third Countries: How Effective? Paper for the ECSA International Conference, Seattle, 1997.

Strange, Austin - Parks, Brad - Tierney, Michael J. - Fuchs, Andreas - Dreher, Axel - Ramachandran, Vijaya: China's Development Finance to Africa: a Media-Based Approach to Data Collection, [online], Working Paper No. 323, April 2013. Source: Center for Global Development [11.08.2017.] DOI: https:// doi.org/10.2139/ssrn.2259924

Strange, Austin - Dreher, Axel - Fuchs, Andreas - Parks, Bradley - Tierney, Michael J.: Tracking UnderReported financial Flows: China Development Finance and the Aid-Conflict Nexus Revisited, [online], Discussion Paper Series 553, University of Heidelberg, January 2014. Source: Sagepub [28.08.2017.] DOI: https://doi.org/10.2139/ssrn.2384103

The New Colonialists: a fourteen-page report on China's thirst for natural resources. [online], 13.03.2008. Source: The Economist [10.08.2017.]

Vines, Alex - Wong, Lilian - Weimer, Markus - Campos, Indira: Thirst for African Oil: Asian National Oil Companies in Nigeria and Angola, [online], 10.08.2009. Source: Chatham House [10.09.2017.]

Wang, Xiaobing - Ozanne, Adam: Two Approaches to Aid in Africa. Paper presented at the International Conference "Ten Years of War against Poverty", University of Manchester, September 2010.

Woods, Ngaire: Whose Aid? Whose Influence? China, Emerging Donors, and the Silent Revolution in Development Assistance. International Affairs, Vol. 84, No. 6, 2008, pp. 1205-1221. DOI: https://doi. org/10.1111/j.1468-2346.2008.00765.x 